\title{
RChaEOlogy AND HeRITAGE
MANAGEMENT In EuROPE: TRENDS AND DEVELOPMENTS
}

\author{
Willem J. H. Willems \\ Dutch State Archaeological Service and \\ the University of Leiden
}

\begin{abstract}
The importance of archaeological heritage management in a united Europe has increased in recent years, and the archaeological scene is changing drastically. Causes of this development are, among others, the end of the political division of Europe and the 'green debate' with its effects on the way in which the archaeological heritage is being treated. Equally important are the effects of the Malta Convention and the influence of lawmaking within the EU. This paper discusses recent developments and the need for cooperation at a European level, as well as the various opportunities, tasks and challenges of heritage management in the immediate future.
\end{abstract}

Keywords: archaeological heritage management, Convention of Malta, European Union, history of archaeology, management cycle

\section{INTRODUCTION}

Archaeology, and especially the management of the archaological heritage in Europe, is going through a period of rapid change. In this paper, based on a lecture delivered at the 1997 Annual Meeting of the British Institute of Field Archaeologists, some recent trends and developments will be explored. ${ }^{1}$ Some of the changes which are visible today, and which are relevant at the European level, are to some extent 'internal' to the discipline. They are related to the development of archaeological heritage management over the past quarter-century. Other changes are more 'exter-

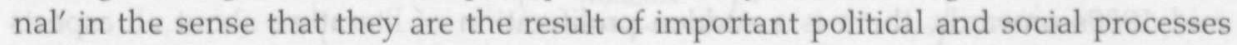
which have changed the map of Europe.

Public involvement with ancient monuments has a long history, if one follows the textbooks citing measures taken by authorities in various European countries in the sixteenth and seventeenth centuries to protect archaeological remains. Indeed it can the European Association of Archaeologists [1461-9571(199812)1:3;293-311;006624] 
be said that such examples are early testimony to governments recognizing the importance of elements of the archaeological heritage as places of remembrance. However, the 'care and protection' of ancient monuments, which in most European countries properly started somewhere in the later part of the nineteenth or in the beginning of the twentieth centuries with the adoption of Monuments Acts, is not the same as the modern concept of heritage management. The idea of heritage as a resource that needs to be managed is in fact a recent development that is an answer to the serious threat to all archaeological remains in modern society.

I have recently analysed this development in the Netherlands (Willems 1997). Although there are differences between countries, essentially the same stages occur everywhere. There is an early phase, which goes hand-in-hand with the development of archaeology as a discipline, and there is a second stage in which Monuments Acts are created and a system is introduced of national inventories, legal protection and other measures, combined with regulation of excavations. Everywhere, the archaeological community was mainly interested in the research and, to some extent, in the documentation aspects. Where a conservation policy existed, that policy was usually limited to registering and legally, sometimes physically, protecting important individual sites, and primarily the visible ones. Archaeological monuments were thus treated as precious individual sites belonging in the national collection. The booming economy in Europe and the disastrous effects on the archaeological heritage caused the same reaction everywhere, in the form of the sometimes very large-scale rescue excavations of the 1960s and 1970s.

Only quite recently did the archaeology profession recognize the enormous threat to the archaeological heritage and the urgent need for a different approach. In the United States this started in the mid-1970s with a landmark publication by Lipe (1974), which was later reprinted more accessibly in Cleere (1984). In Europe, developments began only in the 1980s. Through conferences such as those organized by the Council of Europe in Florence (1984) and Nice (1987), an international debate arose on these issues where formerly, as was already observed with some surprise by Henry Cleere in the introduction to his 1984 volume Approaches to the Archaeological Heritage, this had been lacking (Council of Europe 1987; 1989).

In the international context the archaeological debate, until well into the $1980 \mathrm{~s}$, was about research, not about preservation of the heritage. A simple check in any well-stocked archaeological library or in bibliographies shows that from about the mid-1980s onwards, there is a sudden proliferation of literature about all aspects of heritage management. This lack of international discussion and comparison is not surprising, because the activity of 'caring for monuments' (which is the literal translation of the terminology used in Dutch 'monumentenzorg' and in German 'Denkmalpflege') used to be dominated by legal requirements and administrative procedures. These can differ greatly from one country to the next and an exchange of information about the different systems may not have seemed very relevant. In addition, only a minority of archaeologists was concerned with those issues 
and in previous decades they could usually do very little about them either: the discipline was primarily practised in universities and museums.

In any case, the growing concern and awareness promoted by the international discussion led to a change of the entire concept of how to deal with the archaeological heritage. This marks the start of a third stage of development which in some European countries is now well established, while in others it still has to begin. Archaeological monuments, in the sense of movable as well as immovable parts of the cultural heritage, are no longer seen primarily as objects of study but as cultural resources to be of use and benefit in the present and future. The concept of 'care and protection of monuments' is replaced by a new approach, the 'management' of these archaeological resources, and this cannot be done by viewing them in isolation. It has to be done 'in context': in the context of the natural and the manmade landscape and therefore at a regional scale, in the context of political developments such as the impetus provided by the green debate and, last but not least, in the context of the ongoing land-use planning process. An important notion is also the cyclical nature of this process with a crucial feedback-link between research and management. Figure 1 gives a representation of the archaeological

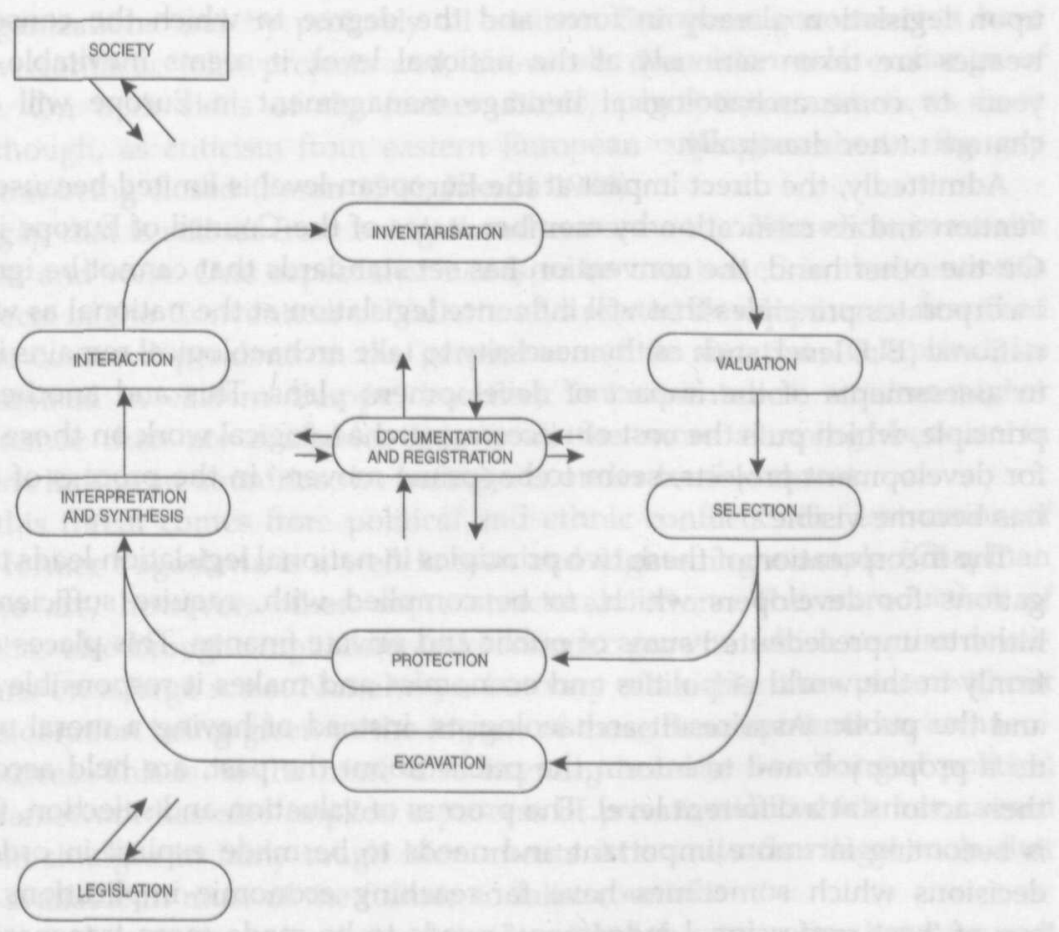

Figure 1 The archaeological management cycle (after Willems 1997). 
management cycle. It shows the different elements or phases of the archaeological process; comparable models have been published elsewhere, such as Baker and Shepherd (1993).

\section{EUROPEAN DEVELOPMENTS}

At the European level, the development described above led to an initiative by the Council of Europe to replace the completely outdated Convention of London of 1969 by a new convention that was prepared by an international committee of the Council of Europe from 1988 to 1991 . It was signed by most European countries at Valletta on Malta in January 1992 and has now been ratified by 13 countries and is already in force in 9 of them. Only a few states have not signed the convention, among others Austria, Belgium, the Czech Republic and Iceland. It has been ratified by Bulgaria, Estonia, Finland, France, Germany, Hungary, Ireland, Liechtenstein, Malta, Norway, Poland, Sweden and Switzerland. A ratification law has also been passed by the Netherlands parliament this year. Dutch and French ratifications imply that the Convention will also be implemented in other parts of the world, notably in South America. Although the effects may vary from country to country, depending upon legislation already in force and the degree to which the consequences of treaties are taken seriously at the national level, it seems inevitable that in the years to come archaeological heritage management in Europe will continue to change rather drastically.

Admittedly, the direct impact at the European level is limited because it is a convention and its ratification by member states of the Council of Europe is voluntary. On the other hand, the convention has set standards that cannot be ignored and it incorporates principles that will influence legislation at the national as well as international (EU) level, such as the necessity to take archaeological remains into account in assessments of the impact of development plans. This and another important principle, which puts the cost of necessary archaeological work on those responsible for development projects, seem to be 'prime movers' in the process of change that has become visible.

The incorporation of these two principles in national legislation leads to legal obligations for developers which, to be complied with, require sufficient time and hitherto unprecedented sums of public and private finance. This places archaeology firmly in the world of politics and economics and makes it responsible to the state and the public. As a result archaeologists, instead of having a moral obligation to do a proper job and to inform the public about the past, are held accountable for their actions at a different level. The process of valuation and selection, for example, is becoming far more important and needs to be made explicit in order to justify decisions which sometimes have far-reaching economic implications. The black box of 'best professional judgement' needs to be made more transparent and the increase in archaeological work is gradually leading to the introduction of commercial archaeological enterprises everywhere. This in turn necessitates the develop- 
ment of standards and specifications, and at the individual level the need is felt for codes of conduct for professional archaeologists.

Such consequences have not met with approval everywhere in the discipline and they are still hotly debated in many countries and in international conferences. At the same time, however, the growing involvement of archaeology with presentday society has led to new theoretical and methodological debates and has opened new lines of research and strongly influenced existing topics of academic research (Hunter and Ralston 1993; Koschik 1995; Willems, Kars and Hallewas 1997).

Apart from the development described so far, there is of course the process of unification and of growing political cooperation in Europe, which influences archaeology and the community of archaeologists in many other ways.

An important event in this respect was obviously the end of the political separation of eastern and western Europe, which has thoroughly changed patterns of communication and cooperation. The existing barriers have been lifted, at least in principle, although social and economic differences are still an important hindrance for colleagues from the former eastern bloc (e.g. Janik and Zawadzka 1996; Slapšak 1993). On the other hand, the special opportunities and funds created by international organizations and by probably all western-European governments have boosted new contacts, joint projects and, above all, discussion and exchange of information. On both sides of the former divide, perceptions and views have changed although, as criticism from eastern European colleagues shows, the gap is still far from being closed (Beran 1996; Jakobs 1996).

Another gap that is still far from being closed concerns the differences in wealth between east and west. One aspect that needs to be mentioned in this context is that the effects of the Convention of Valletta and related developments described above are of course dependent on the general economic situation. The principles may be endorsed in eastern Europe, but their implementation requires higher levels of finance than are available. This is all the more alarming, because in many eastern European countries the heritage is under terrible threat.

In part, this threat comes from political and ethnic conflicts: the destruction of heritage in former Yugoslavia is a well-known and frightening example (Chapman 1994). There are, however, other, more structural factors. The introduction of democracy has also brought capitalism and economic growth, which require development plans on a large scale. Not always, but very often this takes place without proper consideration being given to the impact of these developments on archaeological resources. This is all the more disconcerting because the changed political and legal framework has also implied a process of privatization which has caused unfavourable changes in fairly tough Monuments Acts and other legal tools that used to be available in most of the former socialist countries.

The situation thus seems to be that, while the end of the separation between east and west has in general been beneficial to the community of archaeologists, the effects on the archaeological heritage in eastern Europe are far less beneficial. 
Available tools in heritage management have been affected or have disappeared and, where they have been replaced by new instruments, these are not always very effective because of insufficient levels of finance, precisely at a time when rural and urban development plans are executed at an unprecedented scale.

Another aspect of the process of unification in Europe is the new 'political' role of archaeology. Over the past decade or so, 'culture' in the European Union is increasingly being considered as a key dimension of integration and this has had an influence in many fields (Shore 1996). Archaeology, which is rather susceptible to political use and sometimes suffers from ideological abuse for nationalistic and other reasons, is now also used for purposes serving the European idea. The discipline is obviously well suited to illustrate - and to create public awareness of concepts such as 'common roots' or the limited relevance of modern political boundaries.

A recent example of this is the so-called 'Bronze-Age Campaign', launched by the Council of Europe a few years ago and officially terminated in 1997. The original proposal for the campaign was made by the Swedish state antiquarian Margaretha Biörnstad at a conference in Krakow in 1991, and subsequently adopted by the Council of Europe $e^{2}$. The various activities in the context of this campaign have been quite beneficial to archaeologists working on the Bronze Age period. The reason for the campaign, however, had little to do with Bronze Age research but was primarily intended to promote archaeology and to communicate concepts of common heritage (and its management) at a European scale. That was also the reason why the Bronze Age was chosen, as it conveyed much better than Roman or Viking Age archaeology the notion of a common European identity rooted in the deep past.

The decision to stop the campaign also had little to do with the research aspect of it. It was caused on the one hand by a lack of funds from Strasbourg, and on the other by disappointment at the lack of public interest in the campaign. My guess is that if the aspect of raising public awareness had been more of a success, additional funds to continue the campaign would have been found or, rather, money that is now being spent on something else would still have been available for archaeology.

This is just one illustration of the way in which archaeology has a role in the political process of unification in Europe and of creating a European identity and consciousness. Although this particular example is not a cause for concern and large numbers of archaeologists were actively involved in it in one way or another, it is useful to remember that we don't 'discover' the past but we are always 'constructing' it. This means that there are some ethical questions here, perhaps even moral problems, and definitely some conceptual difficulties that the profession has only just started to discuss (e.g. Graves-Brown, Jones and Gamble 1996). In any case, generating multiform knowledge about the past, which is one of the central tasks of archaeology, is not necessarily served by preconceived ideas about common roots leading to questionable notions about a shared and unitary past 
which sometimes surface when Europe is discussed. In that sense the first article of the Convention of Malta, where the archaeological heritage is described as 'a source of European collective memory', is more neutral. This conveys the idea of archaeological heritage as a source of information, although it remains unclear what precisely it is that is 'European' about it.

That leads to yet another reason for growing involvement with archaeology at the European level, which is the increased role of the European Union. The position of the EU is ambiguous because even though there is, from a European point of view, an ideological attractiveness of being able to point to a collective past, of using the heritage to illustrate all that Europeans have in common, the archaeological heritage is at the same time experienced from a national point of view as an essential part of the culture of the separate states. That is part of the reason why there has been for a long time only a small basis for involvement with the heritage by the Union. Since the Treaty of Maastricht 5 years ago, however, this has changed. We now have the well-known Article 128 of the Treaty on the European Union (see Fig. 2) which is a major step forward in the sense that the EU now has legal competence in the field of culture. The first paragraph of Article 128 reflects the dilemma, but the Article has opened the way for action by the EU which is of major importance.

However, while direct involvement of the EU under this article is very significant, there are several reasons why the effects are limited. First, by the inherent ambiguity which is strengthened by the principle of subsidiarity. This means that the EU only acts in support of, or to supplement, action of Member States. Second, by the limitations in the treaty, which only empowers the Council to adopt 'incentive measures' and 'recommendations'; harmonization of national law is specifically excluded and, even for a relatively light measure such as a recommendation, the treaty requires unanimity in the Council. In practice, programmes proposed by the Commission have to be approved by the representatives of the member states in the Council. As recent developments with the Raphaël Programme have shown (see later), that is not an easy task.

There is also a third reason, namely that the impact of the EU on archaeology is not at all limited to what goes on in the field of culture (or education). Education and culture are areas where the EU has carefully designed programmes for archaeology but, on the other hand, these are fields which are excluded from binding EU legislation, such as regulations, directives and decrees by the Council.

There are many other areas, however, which are in principle unrelated to the cultural sector and where considererations on archaeology play no part in the initial law-making process, in which nevertheless binding EU legislation is produced that may have positive or negative consequences for archaeology. The best example of this is probably the EU legislation on the environmental impact assessment (Council Directive $85 / 337 /$ EEC) of 1985 , which requires an analysis of the environmental effects of certain projects that can include archaeological considerations. The importance of this legislation for heritage management may now be greatly enhanced by the 1997 Council Directive (97/11/EC) that amends the earlier directive and, among 
1. The Community shall contribute to the flowering of the cultures of the Member States, while respecting their national and regional diversity and at the same time bringing the common cultural heritage to the fore.

2. Action by the Community shall be aimed at encouraging cooperation between Member States and, if necessary, supporting and supplementing their action in the following areas:

- improvement of the knowledge and dissemination of the culture and history of the European peoples;

- conservation and safeguarding of cultural heritage of European significance;

- non-commercial cultural exchanges;

- artistic and literary creation, including in the audiovisual sector.

3. The Community and the Member States shall foster cooperation with third countries and the competent international organizations in the sphere of culture, in particular the Council of Europe.

4. The Community shall take cultural aspects into account in its action under other provisions of this Treaty.

5. In order to contribute to the achievement of the objectives referred to in this Article, the Council:

- acting in accordance with the procedure referred to in Article 189b, and after consulting the Committee of the Regions, shall adopt incentive measures, excluding any harmonization of the laws and regulations of the Member States. The Council shall act unanimously throughout the procedure referred to in Article 189b;

- acting unanimously on a proposal from the Commission, shall adopt recommendations.

Figure 2. The text of Article 128 of the Treaty on the European Union.

other improvements, now also includes archaeology in its definitions. This illustrates a growing awareness of the effect of this particular directive.

Another example is the Common Agricultural Policy that has been so very important from the very start of the EU. This policy, which used to stimulate agricultural production, has had an indirect but tremendous negative influence on the survival of archaeological remains all over western Europe. In the Netherlands, for example, it has been estimated that since the end of World War II, 33.1 per cent of the then surviving archaeological remains in the soil had disappeared by 1994. Of that figure, no less than 23.2 per cent was due to intensification of agriculture (Groenewoudt, Hallewas and Zoetbrood 1994). ${ }^{3}$ At present, however, there may be options where EU legislation or programmes in this field might be used positively. For example, 
if a connection can be made between subsidies for farmers to take fields out of production and fields with important archaeological monuments, there could be a very beneficial effect.

This could perhaps be done on the basis of the fourth paragraph of Article 128, which states that the community shall take cultural aspects into account in its action under other provisions of this Treaty'. In this respect, it is noteworthy that the recent strategy document Agenda 2000 of the European Commission contains a considerable number of proposals related to changes in the structural funds and the common agricultural policy that could be useful. Most notably, in framing its reform proposals, the Commission has given a new priority to rural development and wants to make it more environmentally sensitive.

The same fourth paragraph of Article 128 can of course be used in many other types of legislation. This is increasingly realized at the European level and some progress has been made (European Union 1996). In January 1998, the Directorate General X, which is concerned with culture, organized a public forum to discuss proposals for a new, single-framework cultural programme of the EU. Although discussions between European politicians, civil servants and organizations from the field of culture yielded a bewildering number of proposals, ideas, and viewpoints, there were a few common themes. One unanimous conclusion was that taking cultural aspects into account in other actions should be a major priority. The same conclusion has also been incorporated in the Council Decision (97/C305/01) of September 1997, regarding the future of European cultural action. This same Decision requires the Commission to present new proposals on cultural action by May 1998, so presumably these will have been announced by the time this article is published.

\section{AN AGENDA FOR THE FUTURE}

The development of new concepts of heritage management as well as the political processes of unification and cooperation have led to an increased awareness of, and interest in Europe by the archaeological community. One of the results of this European awareness has been the founding of the European Association of Archaeologists. The initiative came out of a group who had originally intended to start a 'Journal of European Archaeology', partially in combination with another group, consisting of members from the committee that had drafted the Convention of Malta. The EAA had its inaugural meeting in Ljubljana in Slovenia in 1994. All those involved with its foundation were deeply convinced that the profession should organize itself at the European level and that this should be a very broad organization that would truly unite the archaeologists of Europe.

That is a very ambitious goal and, although the EAA has not yet reached it, the association has indeed become a medium for uniting archaeologists from east and west and from all different kinds of backgrounds - universities, museums, heritage management, private enterprise, etc. - and most specializations. 
The journal, now called European Journal of Archaeology, is developing into an important forum for international discussion. The EAA also has a newsletter, and options for a site on the internet are being investigated, but most important as a forum and medium of discussion are the annual meetings with sessions, round tables and other events where all issues that are relevant to archaeology in Europe can be discussed. There are annual conferences at the national level in a number of European countries, but it is an important step forward that there is now a functioning annual meeting in Europe. For the future of European archaeology it is very important that there is a democratic organization that offers a platform for discussion and exchange of opinion.

That does not mean that there are no problems. Europe is a multicultural entity, only part of which is politically and economically united in the EU. This causes various problems when we want to cooperate, discuss important issues, and exchange information, and the EAA has probably been confronted with all of them.

One important issue is language. If we want to communicate, we have to speak the same language and that is not always easy. Although the author is Dutch, it would not make much sense to publish this article in Dutch. It is an unfortunate consequence of the rise of the nation-state that in the nineteenth century the scientific community in Europe has had to stop using Latin as a lingua franca. In the Scandinavian countries or the Netherlands, academia has long been forced to deal with this problem: most people'speak foreign languages and there are budgets for translation. A similar development has now started in many eastern European countries. In larger countries and language areas, this has not always been the case. For purely financial reasons, the EAA has decided to adopt English as its official language: it simply cannot afford to be obligated to provide translations although in practice this is done wherever possible, with members preparing translations of important documents such as statutes. During meetings all major European languages are admitted as long as simultaneous translation is provided.

Still, the language question always comes up. It is an emotional and political problem that cannot really be solved; it is not unique to archaeology, of course, although our discipline is strongly affected by it because finances for professional translation are usually lacking. If the problem is handled in an insensitive way, it can easily become a major hindrance in the international cooperation we want so badly. In addition to these problems, there are sometimes also formal obstacles. In France, for example, there is specific legislation concerning the mandatory use of the French language.

A related field of problems is cultural differences. In international organizations and in companies working at a European scale, anthropologists and sociologists nowadays make a living by training members or employees in handling behavioural differences related to cultural background that affect management and organization (e.g. Tayeb 1994). In our discipline, we may be slightly more aware - and perhaps even tolerant? - of cultural differences than in business or administration, but taking them into account is essential for future cooperation. 
They may also be the underlying reason for things that we don't usually recognize as such. For example, membership numbers of the EAA vary widely from country to country. There are some objective reasons for that, in the sense that there may have been more effective promotion in one country than another, but the way in which archaeology is organized nationally, its structure, conventions and traditions, in short, the archaeological culture, determines how an organization such as the EAA is looked upon. In any case, these are problems that can be identified and will be remedied in due time as far as the EAA is concerned. All communication in an international context is, however, determined by cultural differences that we should be aware of if we want to cooperate successfully.

A third field of problems is political differences. Archaeology's changed role in modern society and the growing interrelationship between the management of archaeological resources and social and economic development imply that political views are much more relevant within all branches of the profession than they were before. The development of theoretical archaeology since the 1960s has, of course, generated 'neo-Marxist', 'feminist', 'critical' and other approaches and in practice there have always been the politically dependent power structures within the discipline. The controversy over the Southampton 1986 World Archaeological Congress is a recent case where political viewpoints played an important role. Another example is that in some Nordic countries there has apparently been a politically motivated reluctance among some groups of archaeologists to be involved with the EAA, because of the (incorrect) assumption that the association was directly related to the EU. In any case it is clear that, when international cooperation is at stake, political sensitivities must be taken into account.

Although the EAA is largely an organization of private individuals, it is not a body for professional archaeologists at the European level, such as the Institute of Field Archaeologists (IFA) in Britain, Professional Association of Spanish Archaeologists (APAE) in Spain or the Nederlandse Vereniging van Archeologen (NVvA) in the Netherlands. The EAA is primarily for professionals, but in principle anybody can be a member. Nevertheless, it has now adopted a code of practice, to make explicit the ethical principles to which any European archaeologist and EAA member should adhere (The European Archaeologist 1997, 7-8).

It is likely, however, that more will have to be done in the not too distant future. The Dutch association of professional archaeologists NVvA has been founded partly because in the near future private enterprises are expected to be able to work in archaeology in the Netherlands. To a certain extent they have already done that for some time, but there is no market yet for excavation work. Private enterprise in excavation is explicitly ruled out by Dutch law, which only allows the State Service (ROB), university departments and municipal archaeologists to excavate, but that will all change with the implementation of the convention of Malta in the Dutch Monuments Act (Willems 1997). As a consequence, we will need a system of quality control that so far nobody has bothered about and that implies all kinds of things we did not have before, such as guidelines, standards and specifications for 
archaeological work. In addition, standards have to be set for both commercial and other organizations and a mechanism is required to ensure quality at the individual level. The association's functions and aims are to maintain a register.

One of the things that may happen as a consequence of these changes in the existing archaeological order is that non-Dutch companies might want to do excavation work in the Netherlands. Perhaps this will be one of the consequences of EU regulations on economic competition and tendering and this may be a second instance, perhaps even a very important one, where EU regulations which in themselves have nothing to do with archaeology turn out to have a major effect in our field. This is still uncertain, however, and there exist official reports from various countries in which jurists give varying and partially conflicting opinions. In any case, one can see that in the future there may well be a need to establish shared views on ethics, professional standards and public accountability at a European level. A similar development has taken place recently in the USA, where the Society of Professional Archaeologists has now been replaced by ROPA: a nationwide Register of Professional Archaeologists. Although there is an important difference - Europe is not a nation - we may well need something similar in Europe and the EAA might cooperate with the various national associations to organize and maintain a common framework.

Of course all these issues of commercialization, European tendering, development of standards, professional ethics or practice, etc. are on the agenda of the EAA meetings and that is, as mentioned earlier, a major function of the organization as a platform for discussion. On the other hand, important as discussions may be, there is more to do than just talk.

The EAA has been working these past years to develop into an organization that can represent the interests of archaeology and archaeologists at the European level, that can be consulted by the European Union, by the Council of Europe (see Fig. 3) or by other international bodies on issues involving archaeology, and that can function as a pressure group or moral authority. Of course there has always - from the very start of the organization - been the idea that it might be able to actually start lobbying in Brussels, but this is rather expensive to handle professionally. It is quite clear that all sorts of decisions made in Brussels will increasingly become more important and more relevant for archaeology.

For the time being, there are the programmes such as Socrates, which is supported by Directorate General XXII for Education, and the Rafaël Programme of the Directorate General X for Culture. The latter has already been referred to above. It was finally approved in October 1997 after discussions that lasted more than two years. On the one hand there was the Commission, who proposed it and was supported by the European Parliament; on the other, there was the Council of Ministers who refused to approve the original proposal. Article 128 of the EU Treaty is one of the articles where the European Parliament has increased powers (codecision) while the Council has to decide unanimously instead of by qualified majority. In combination with the complicated procedure necessary to reach an 

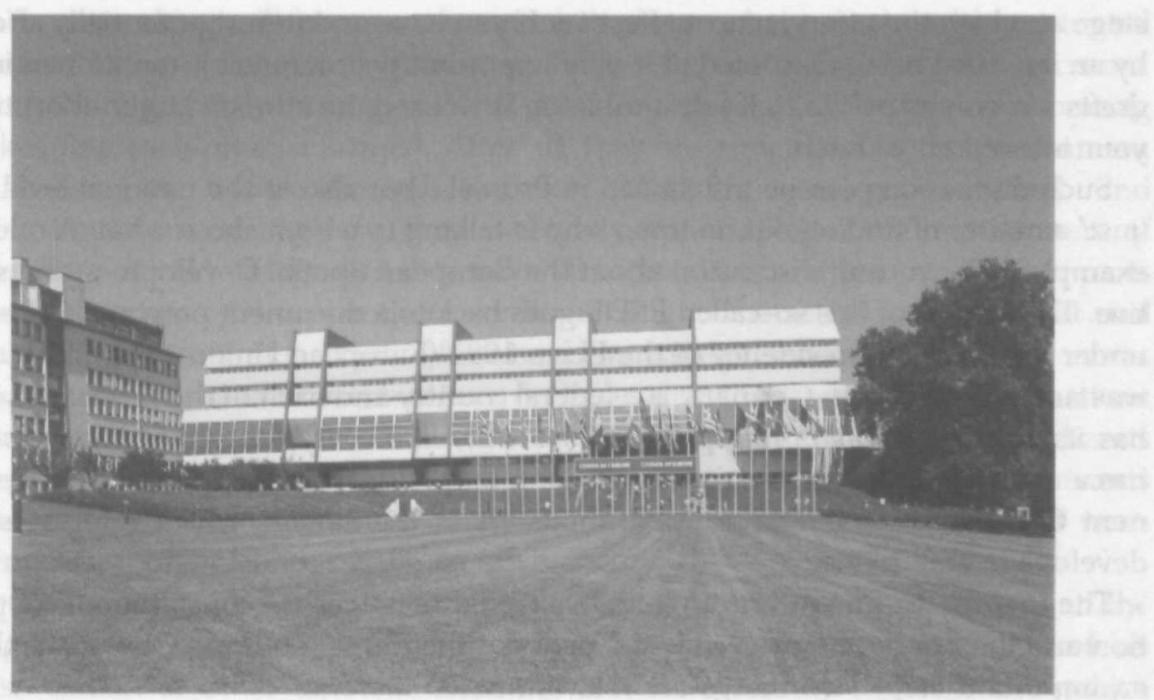

Figure 3. The European Parliament in Strasbourg.

agreement, this can lead to a long-drawn-out process. It was the UK, Germany, the Netherlands and Austria that had problems, because it was apparently felt that the objectives of Rafaël in the field of cultural heritage were in fact within the domain of the member states so the EU should not spend money on them.

There are probably other reasons as well, but it is important to note that the opposition was generated at the national level, within the relevant ministries of the governments involved. Despite the obvious importance for archaeology, an effort to persuade these governments to be more forthcoming in the negotiations would not be something that can be achieved by a private organization such as the EAA. In this case, cooperation between national organizations for heritage management who are all tied into the decision-making process within their national government could be more effective. This illustrates on the one hand that not all things must be achieved in Brussels and, on the other, that an organization of private individuals such as the EAA is not always the most suitable medium.

A similar situation exists in the process of policy-making within the EU: all sorts of themes are discussed, also in areas where there can be no binding legislation at the European level, and there are various mechanisms by which such discussions take place. There are, for example, the drafting-committees employed by the Commission in Brussels. These committees are usually composed of experts who prepare draft documents for the Commission. There are also policy documents which are prepared in other ways, without the explicit or at least the immediate purpose of generating binding legislation. Whatever the case may be, it is very important to influence such discussions as early in the process as possible because this is the 
stage at which the effort is most effective. If you have an interest potentially affected by an initiative being discussed, it is very important your interest is mentioned in the drafts as soon as possible. If left until later, it will require a much larger effort to get your interest considered.

Such discussions can be influenced in Brussels, but also at the national level. It is 'just' a matter of finding out, in time, who is talking to whom about what. A relevant example is the current discussion about the European Spatial Development Perspective. The history of this so-called ESDP goes back to a document prepared in Leipzig under the German presidency of the EU in 1994 (European Union 1994; 1997). That was not a coincidence: Germany is a federal country and each of the German Länder has its own spatial planning policy. Obviously, like every other country, Germany has a need for an integrated, national planning policy. That is achieved by a permanent Conference of the responsible ministers of the Länder, which integrates and develops overall plans.

The Leipzig document was an initiative to start a process of consultation, cooperation and the development of a spatial policy at the European level. Obviously, this is an important step. Two things are relevant here.

First, any development in spatial planning at the European level is very important to archaeology: the connection between the management of the archaeological heritage and spatial planning may long have been neglected, as is now almost self-evident. At the moment, the real importance of the ESDP initiative is limited because it is not a proposal for European legislation by the Commission and there is no serious money attached. Europe is not a federal country and the role of the European ministers' conference is much more restricted than that of the internal, German ministers' conference. Nevertheless, it is important that the roles of the cultural heritage in general and, where possible, that of the archaeological heritage in particular, are incorporated in such a document. This has led the Dutch State Archaeological Service to consult with the Dutch Ministry for Spatial Planning in order to get into the draft document some statement about the role of the European archaeological heritage. If archaeology is recognized at an early stage, the chances are that its role will also be duly recognized if and when this growing European cooperation will have any serious consequences.

However, the second aspect that is important about all this is that the ESDP process has remained largely outside the view of archaeological heritage management circles ever since 1994. In the Netherlands, we had not heard of it before and we were put on its track only very late, in the context of the Dutch presidency of the EU. Only then did we find out about the Leipzig paper and did we learn that, since 1994, the developing initiative had passed from one country's Ministry for Spatial Planning into the hands of the next. The role of cultural heritage is definitely recognized in the draft report, by the way, but we have not been able to achieve explicit recognition of the specific position of archaeology. However, we were late and we acted only as the Dutch government institute, without any previous networking with colleagues elsewhere. 
Such networking will become ever more important, because there is a potential influence that national organizations may have on processes of European decisionmaking which go partly through national channels, especially if they are collaborating and keeping each other informed. After all, they are either part of the government and belong to a specific ministry, or they are semi-governmental and semi-autonomous. In any case, they are legally responsible for the management of the archaeological heritage and they have all sorts of ties and links with other parts of the government. Of course there are limitations to the actual influence that civil servants in a state antiquarian's office or a comparable service have, and it varies from one country to the next, but they do have access where private organizations cannot reach. Once the politically responsible level has taken a decision the hands of a governmental and legally responsible organization are tied: as civil servants they cannot go against political decisions. In those situations, private and nongovernmental organizations have an advantage.

It is obvious, therefore, that archaeology needs another organization at the European level, in addition to the EAA and working complementarily. Therefore, an association or other umbrella-structure is needed for the organizations which are legally responsible for archaeological heritage management at the national level. Sometimes, such as in Britain, in Germany or in Spain, it must be at a lower level because that lower level is where the cultural autonomy lies in those countries. Such an additional association could work successfully where the EAA is less efficient and vice versa, and it could provide the backbone for a network of practical cooperation in heritage management.

For 4 years now, directors of the official organizations have been meeting in various contexts and an informal round table has constituted itself. During its last meeting in September 1998, with delegates from organizations in 20 countries, the need for structured cooperation at the European level was confirmed unanimously. An association will probably be started in 1999. The process required lengthy discussions because the sometimes very different organizational and administrative structures at the national levels had to be taken into account.

\section{OTHER TOOLS}

As mentioned earlier, the EAA might work together with national professional organizations to develop standards and ethics at a European level. That is just one of the many tools that are still lacking if the profession is to become truly European in scope. Again: some of these tools can be more adequately developed by a private and democratic body such as the EAA, others may be more easily realized by cooperating heritage-management organizations.

An example of this is a fairly small project of cooperation started by the Dutch State Service and the German organization for the Rhineland, the Rheinisches Amt für Bodendenkmalpflege. We have chosen a small region on both sides of 
the border for a survey project intended to learn to speak each others' languages. There are many spatial developments across the border nowadays and both organizations felt they should work together more closely to properly deal with those. This is not the place to go into the details of the research project (Deeben et al. 1997). The point is, that although literally we do speak each others' languages and there have been close ties between Dutch and Rheinland archaeology for decades, it is astonishing how much is different. Field techniques are comparable but not the same; we discovered that interpretation in the form of categorization of types of sites had subtle differences that needed to be made explicit; we were confronted with the fact that there are excellent German soil maps and equally excellent Dutch maps, but that they do not match. The reason is that the German and Dutch soil surveys use different criteria so they need to be reinterpreted, which is quite complicated. These are problems of a kind that have hardly been noticed so far. They show the deplorable level of international coordination and the formidable barriers that exist when bilateral - let alone multilateral - cooperation is attempted. There are also problems that seem to have been neglected by academic research and now need to be tackled by heritage management.

Another good example is scientific terminology. It would be an immensely valuable research tool today, if national databases of archaeological sites and finds could be interconnected and direct communication could be possible. In the future, this will become absolutely necessary. In order to make that possible, we shall need core data standards and we shall also need a terminology that is mutually understandable and - most important - that is unambiguous. One would expect this to be available, but it is not. In the context of the European Bronze Age Campaign mentioned earlier, it has been possible to start the preparation of a multilingual glossary of archaeological terminology. This was only achieved because of a smart proposal that limited the chronological scope to the Bronze Age. The glossary has been prepared in English, French, German, Dutch, Danish and Rumanian. Other languages still need to be added, but a start has been made.

It is only through cooperation at a European level that such tools will become available. In most cases, real progress can only be made when there are more options for financial participation by the EU, although cooperating organizations for heritage management might be able to raise some funds.

A powerful tool may be provided by the new medium for communication which is the internet. It is very important that, under the Socrates programme, the European Union has recently decided to fund the 'archaeonet'. It is a DG XXII project, and understandably it is primarily aimed at developing and strengthening academic links throughout Europe via the World Wide Web, but its effect may become much broader. Heritage management links and a forum for easy communication may well be incorporated in the archaeonet, now that it exists. As I have already mentioned, reaching consensus through communication is essential for future developments. 
When looking at the future, there is reason to be fairly optimistic because one can see in our profession an increased awareness of transnational developments and a general interest in the practice of archaeology at the European level. More important: this is an interest that is growing. Europe is on the agenda of our discipline.

That does not mean that all is well. Beyond the probably widespread conviction that the archaeological heritage is rapidly deteriorating, it is doubtful if the archaeologists of Europe share the same views on the challenges that our discipline will have to meet in the next decade or so, and on the priorities. There is, however, a willingness to discuss the issues and to cooperate. From the themes that surface when a programme for the EAA meetings is put together, it also appears that there is a growing consensus about the major issues. Of course the colleagues that participate in these meetings are a particular selection from the total community of archaeologists in Europe, but it suggests that we are indeed getting our priorities right. There is also an increase in the means to communicate that are available to us because we did not have media such as the archaeonet or the EAA until quite recently. Communication is difficult, however, because we still have problems understanding each others' languages, both literally and metaphorically. Nevertheless, on the whole there seems to be reason for optimism. Important problems have been identified and mechanisms for concerted action are in place or are being developed. The beginning of the next millennium will hopefully see an organized and effective response of the archaeological community to the challenges of a changing Europe.

\section{NOTES}

1. The lecture will also be published separately by the IFA.

2. This was the CSCE symposium on Cultural Heritage. The CSCE is the 'Conference on Security and Cooperation in Europe'.

3. A similar and much more extensive study is now available for England (Darvill and Fulton 1998).

\section{REFERENCES}

BAKER, D. and I. SHEPHERD, 1993. Local Authority opportunities. In J. Hunter and I. Ralston (eds), Archaeological Resource Management in the UK: 100-14. Bath: Allan Sutton/IFA.

BERAN, J., 1996. On social psychology and the professional self-assessment of the last generation of East-German archaeologists. Journal of European Archaeology 4:3944.

Chapman, J., 1994. Destruction of a common heritage: the archaeology of war in Croatia, Bosnia and Hercegovina. Antiquity 68:120-6.

Cleere, H. (ed.), 1984. Approaches to the Archaeological Heritage. Cambridge: Cambridge University Press.

COUNCIL OF EUROPE, 1987. Archaeology and planning. Report of the Florence Colloquy. Architectural Heritage Reports and Studies, 5. Strasbourg: Council of Europe. 
COUNCIL OF EUROPE, 1989. Archaeology and major public works. Report of the Nice Colloquy. Architectural Heritage Reports and Studies, 12. Strasbourg: Council of Europe.

DarVILL, T., and A. K. Fulton, 1998. MARS: The Monuments at Risk Survey of England, 1995. Main Report. Bournemouth and London: Bournemouth University and English Heritage.

DeEben, J., N. Andrikopoulou-Strack, R. Gerlach, J. Obladen Kauder and W.J.H. WILLEMS, 1997. Cross-border cooperation in archaeological heritage management: the Niers-Kendel project. In W.J.H. Willems, H. Kars and D.P. Hallewas (eds), Archaeological Heritage Management in the Netherlands: 282-95. Assen: Van Gorcum.

EUROPEAN UNION, 1994. European Spatial Planning. Informal Council of Spatial Planning Ministers, Leipzig, 21/22 September 1994. Bonn: European Union.

EUROPEAN UnION, 1996. First Report on the Consideration of Cultural Aspects in European Community Action. Brussels: European Union.

EUROPEAN UnION, 1997. European Spatial Development Perspective (ESDP). First official draft. Meeting of Ministers responsible for spatial planning of the member states of the European Union, Noordwijk 9/10 June 1997. Den Haag: European Union.

Graves-Brown, P., S. Jones and C. GAMBLE (eds), 1996. Cultural Identity and Archaeology. The Construction of European Communities. London/New York: Routledge.

Groentwoudt, B.J., D.P. HAllewAS and P.A.M. ZoetBroOD, 1994. De degradatie van de archeologische betekenis van de Nederlandse bodem. Interne Rapporten $R O B, 8$. Amersfoort: ROB.

HunTER, J. and I. RALSTON (eds), 1993. Archaeological Resource Management in the UK. Bath: Allan Sutton/IFA.

JACOBS, J., 1996. Zur Wissenschaftsstrategie in der deutschen Archäologie seit 1990. Journal of European Archaeology 4:45-54.

JANIK, L. and H. ZAWADZKA, 1996. One Europe - one past? In P. Graves-Brown, S. Jones and C. Gamble (eds), Cultural Identity and Archaeology. The Construction of European Communities: 116-24. London/New York: Routledge.

KoschIK, H. (ed.), 1995. Situation und Perspektiven archäologischer Denkmalpflege in Brandenburg und Nordrhein-Westfalen. Materialien zur Bodendenkmalpflege im Rheinland, 4. Köln: Rheinland-Verlag.

LIPE, B., 1974. A Conservation Model for American Archaeology. The Kiva 39:213-45.

SHORE, C., 1996. Imagining the new Europe: identity and heritage in European Community discourse. In P. Graves-Brown, S. Jones and C. Gamble (eds), Cultural Identity and Archaeology. The Construction of European Communities: 96-115. London/New York: Routledge.

SLAPŠAK, B., 1993. Archaeology and the contemporary myths of the past. Journal of European Archaeology 1:191-5.

TAYEB, M., 1994. Organizations and national culture: methodology considered. Organization Studies 15(3):429-46.

WilLEMS, W.J.H., 1997. Archaeological Heritage Management in the Netherlands: past, present and future. In W.J.H. Willems, H. Kars and D.P. Hallewas (eds), Archaeological Heritage Management in the Netherlands: 3-34. Assen: Van Gorcum.

Willems, W.J.H., H. KarS and D.P. Hallewas (eds), 1997. Archaeological Heritage Management in the Netherlands. Assen: Van Gorcum. 


\section{BIOGRAPHICAL NOTE}

Willem J.H. Willems is Scientific Director of the Dutch State Archaeological Service (ROB) and Professor of Roman Archaeology at the University of Leiden. His research has centred on provincial Roman archaeology and on aspects of heritage management. He has also been involved with various initiatives aimed at organizing archaeology at a European level. Publications include Romans and Batavians (Amsterdam) and Archaeological Heritage Management in the Netherlands (Assen).

Address: ROB, Kerkstraat, 3811 CV, The Netherlands. [email: w.willems@archis.nl]

\section{ABSTRACTS}

\section{Archäologie und Management des archäologischen Erbes in Europa: Trends und} Entwicklungen

Willem J.H. Willems

Archäologische Denkmalpflege als gesellschaftliche Aufgabe wird im vereinten Europa immer wichtiger und die archäologische Landschaft verändert sich tiefgreifend. Ursachen sind u.a. das Ende der politischen Spaltung Europas und die 'grüne Debatte' samt ihre Auswirkungen auf den Umgang mit dem archäologischen Erbe. Ebensowichtig ist die Auswirkung der Konvention von Malta und den Einfluß der EU Gesetzgebung. In diesem Beitrag werden die rezente Entwicklungen diskutiert, sowie die Notwendigkeit der Zusammenarbeit auf europäische Ebene und die verschiedene Chancen und Aufgaben der Bodendenkmalpflege in den nächsten Jahren.

\section{Archéologie et gestion du patrimoine en Europe: tendances et évolution Willem J.H. Willems}

L'importance portée à la gestion du patrimoine archéologique au sein d'une Europe unie a augmenté pendant les dernières années et le paysage archéologique est en train de changer d'une manière considérable. Les causes de cette évolution sont, entre autres, la fin de la division politique de l'Europe et le "débat vert" dont les effets se font sentir dans la manière dont on traite le patrimoine archéologique. Les retombées de la Convention de Malte sont aussi très importantes de ce point de vue, ainsi que l'influence des lois passées à l'intérieur de l'union européenne. Cet article porte sur les récents développements, le besoin de coopération au niveau européen, les différentes possibilités pour ce qui est de la gestion du patrimoine ainsi que de son coût dans un futur proche. 